\title{
Is the Higher Employees' Resilience, the Higher Their Work Engagement Will Be?
}

\author{
Purwanti Dyah Pramanik*, Triana Rosalina Dewi, Rahmat Ingkadijaya \\ Sekolah Tinggi Pariwisata Trisakti \\ *purwanti@stptrisakti.ac.id
}

\begin{abstract}
Hotel is a labor-intensive industry which until now still requires a lot of human resources in its work operations. The nature of hotel is open for 24 hours to serve guests, especially in operational departments. Overall hotel employees tend not to last long at work. Some employees state that their decision to leave, due to incompatibility with the work environment. This study aimed to analyze the impact of resilience on hotel employees' engagement in Jakarta. The study was conducted with a quantitative descriptive approach. Research respondents were hotel employees in Jakarta area. Data was collected by convenience sampling, by distributing questionnaire which consisted of respondents' profiles and statement of variable $\mathrm{X}$ variable (resilience) and $\mathrm{Y}$ variable (work engagement). The data was analyzed by using validity and reliability test, descriptive (frequency and mean), Pearson correlation, coefficient determination and simple linear regression test. The study found that there was a strong relationship between resilience and work engagement. The higher employees' resilience is, the higher employee engagement will be.
\end{abstract}

Keywords: resilience, work engagement, employee, hotel. 


\section{A. Introduction}

Hotel is a labor-intensive industry, and up to now they still needs a lot of human resources for their operational. A five-star hotel with around 550 rooms has about 350 employees (Gisela/ Talent \& Culture Manager, 2019). Since they employ permanent employees and non-permanent employees, in some cases they still recruit daily workers or seasonal employees to run the operational jobs. A five-star business hotel in Central Jakarta needs approximately daily worker of sixty persons (Yasin, HR Manager, 2019).

The nature of hotel operational is open 24 hours for serving the guests. It drives all the employees work harder -especially in the operational job-than the employees in other business. The employees in operational unit work in three shifts. The employees in the first shift can't leave if the second shift employees haven't arrived to continue the duty. If the employees decide to leave without waiting for the next shift' employees, there may the problems in assisting the guests. Unfortunately, this condition is often happened. This situation is certainly detrimental for employees on the previous shift.

Until now, hotels in the Jakarta and surrounding areas still rely on human resources (employees) in carrying out day-to-day work operations. Employees often lack of discipline at work, for example they come late to the office, or they do not empathize of time losses of their colleagues.

Based on literature studies, organizational performance will be good if the employee's relationship is good. This positive environment will cause work engegement. But work engagement will vary, and one of them depend on one's resilience. This study aimed to identify 'The effect of employees' resilience on their work engagement at hotels in Jakarta.'

\section{B. Literature Review \\ Resilience}

Resilience is the capacity of a person to overcome negative emotions and adapt to a changing environment (Hu et al., 2015; Niitsu et al., 2017) or one's ability to deal quickly with unpleasant events that they experience (Fagan, 2019) . Four characteristics of individuals, who have resilience, are: (1) control; (2) commitment; (3) challenges; and (4) connection. This control means that an employee is able to stay focused on his work. While commitment means the employee is consistent with the values he believes in. An employee who has resilience will read challenges as opportunities. Finally connection means being able to establish broad relationships. Resilience can be linked to various scientific disciplines, including social science (Southwick, 2014). Masten (2001) explains resilience is a phenomenon of positive adjustment when faced with a problem. An employee's resilience is very important so it is not easily influenced by negative behavior (Riff and Singer, 1996). Resilience of each individual employee is very dependent on physical and psychological conditions (Connor and Davidson, 2003). An employee who always prepares himself for various risks 
that might arise in his work tends to be able to minimize the effects of stress they experience. (Frederickson, et al., 2008).

\section{Work Engagement}

The term work engagement is a widely discussed topic in the hospitality industry (Karatepe et al., 2014; Li et al., 2012). Work engagement can be described as positive behavior, totality, and focus on work and this can be seen from the existence of enthusiasm, dedication and work appreciation (Schaufeli et al., 2014; Rian, 2017). Employee behavior such as innovative behavior (Yho, 2018) is influenced by work engagement (Yucheng, 2017). Work engagement is a picture of employee relations with the work environment (Schaufeli et al., 2006; Christian et al., 2011). Research on employees in five-star hotels in Northern Cyprus (Karatepe, 2014) found that work engagement is related to organizational commitment and performance. Furthermore Li et al. (2012) examined organizational behavior in large hotels in South China, and found that leadership changes could affect work engagement and subsequently have an impact on performance. Riff and Singer (1996) found that an employee who had higher resilience is not easily influenced by negative behavior such as decrease his/her enthusiasm, dedication, and work appreciation (Schaufeli,W.B.,et.al., 2006)

Conceptual framework is on figure 1.

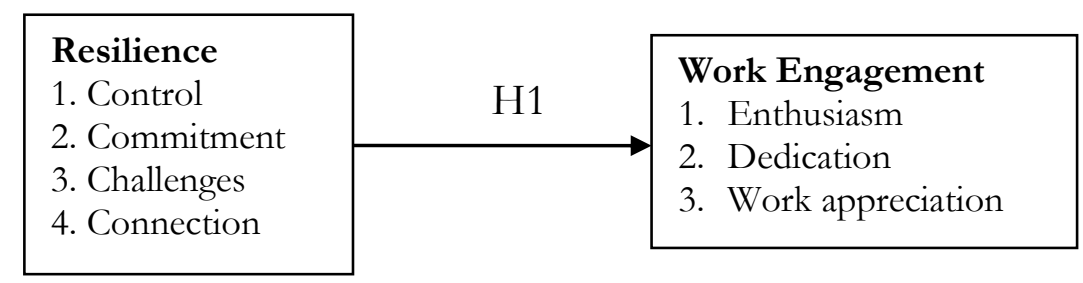

Source: Schaufeli,W.B.,et.al (2006)

Figure 1. Concepual framework

Hypothesis (H1):

Ho: There is no positive and significant effect between employees' resilience and their work-engagement at hotels in Jakarta.

Ha: There is a positive and significant effect between employees' resilience and their work-engagement at hotels in Jakarta. 


\section{Research Methodology Population and Sampling}

The population is hotel employees in Jakarta. The study used convenience sampling to choose the respondents. The respondents were 266 persons who work in a various four star hotels in Jakarta.

\section{Instrument}

The data was collected by distributing questionnaire. The questionnaire is divided into three parts. The first part asked of respondents' profile. It included gender, age, job's unit, position, employees' status, work experience at the hotel. The second part elaborated respondents' perception of their resilience which covers their control, commitment, challenges, and connection. The third part elicited respondents' perception of their work engagement. Likert scale of 5 points was used to measure both variables.

\section{Data Analysis}

The data analyzed by using validity and reliability test, frequency test, descriptive test, Pearson correlation test, coefficient determination, linier regression test, and t-test.

\section{Result and Discussion}

The tests are validity and reliability test, frequency test, descriptive test, correlation test, coefficient determination, linier regression test, and t-test.

\section{Validity test}

In order to test the validity of the "employees' resilience" variable, r-value as a result of SPSS is compared by $r$ table. If the value of $r$-count $>r$-table, the statements that were submitted to the respondents were valid. If the value of $r$ count $<$ r-table, the statement that were submitted to the respondents weren't valid. The value of $\mathrm{r}$-table is done by using the formula $\mathrm{df}=\mathrm{N}-2$, where $\mathrm{N}$ is the number of respondents. Thus obtained $\mathrm{df}=264$. This number is used to find the value of r-Product Moment in r-table. Product Moment r-value was 0.159. R-count for each statement on the questionnaire between $0.530-0.756$ or $>\mathrm{r}$ table (0.159). Then all statements of employees' resilience variables submitted to respondents were valid. For the validity of the variable "employees' work engagement", the study found that r-count for each statement on the questionnaire between $0.565-0.830$ or $>\mathrm{r}$ table (0.159). Then all statements of employees' work engagement that was answered by respondents were valid. 


\section{Reliability Test}

Table: 1 Reliability Statistic of employees' resilience

\begin{tabular}{rr}
\hline $\begin{array}{c}\text { Cronbach's } \\
\text { Alpha }\end{array}$ & N of Items \\
\hline .925 & 13 \\
\hline
\end{tabular}

Reliability tests can be performed by using Cronbach's Alpha values. If the Cronbach's Alpha value> 0.6 then the statement on the questionnaire is reliable, but if the Cronbach's Alpha value $<0.6$ then the statement on the questionnaire is not reliable or consistent. Based on the results of the study, the value of Cronbach's Alpha is $0.925(>0.6)$ for the thirteen statements about employees' resilience. So that all statements of employees' resilience are reliable.

Table: 2 Reliability statistic of employees' work engagement

\begin{tabular}{cc}
\hline $\begin{array}{c}\text { Cronbach's } \\
\text { Alpha }\end{array}$ & N of Items \\
\hline .931 & 8 \\
\hline
\end{tabular}

Based on the results of the study, Cronbach's Alpha value is $0.931(>0.6)$ for the eight statements about employees' work engagement. The statements about employees' work engagement are reliable.

\section{Frequency and Descriptive (Mean) Test}

According to frequency test found that the respondents are: (1) $65 \%$ male and $35 \%$ female; (2) $19.5 \%$ at the age of 25 years old or less, $39.1 \%$ at the age of 26 up to 35 years old, $29.7 \%$ at the age of 36 up to 45 years old, $11.7 \%$ at the age more than 46 years old; (3) $12 \%$ less than a year work experience, $72.9 \% 1$ up to 5 years work experiences, $11.7 \% 6$ up to 10 years work experiences, and $1.1 \%$ for the work experience in the year of 11 up to 15 years, 16 up to 20 years, 21 years and above. Those are described on table 3 Frequency test of respondents' profiles. The study also counts frequency for employees' resilience and employees' work engagement that is described on table 4 and table 5 .

Table: 3 Frequency test of respondents' profile

\begin{tabular}{llr}
\hline Descriptions & & Percentage \\
\hline Gender & Male & $65 \%$ \\
& Female & $35 \%$ \\
\hline Age & 25 years or less & $19.5 \%$ \\
& $26-35$ years & $39.1 \%$ \\
& $36-45$ years & $29.7 \%$ \\
& 46 years and above & $11.7 \%$ \\
\hline Work experience & Less than 1 year & $12 \%$ \\
& $1-5$ years & $72.9 \%$ \\
& $6-10$ years & $11.7 \%$ \\
& $11-15$ years & $1.1 \%$ \\
& $16-20$ years & $1.1 \%$ \\
& 21 years and above & $1.1 \%$ \\
\hline
\end{tabular}


Table: 4 Employees' resilience profiles

\begin{tabular}{|c|c|c|c|c|c|c|}
\hline \multirow[t]{2}{*}{ Descriptions } & SD & DA & $\mathrm{N}$ & A & SA & Mean \\
\hline & & & \multicolumn{4}{|l|}{$\%$} \\
\hline \multicolumn{7}{|l|}{ Controlling: } \\
\hline I am able to control my behavior. & 1.9 & 0.8 & 11.7 & 57.5 & 28.2 & 4.09 \\
\hline I think carefully before I act. & 1.5 & 0.8 & 10.9 & 56.8 & 30.1 & 4.13 \\
\hline \multicolumn{7}{|l|}{ Commitment: } \\
\hline People think that I have excellent spirit. & 0 & 1.1 & 24.1 & 51.9 & 22.9 & 3.97 \\
\hline I have strong personality. & 0 & 1.1 & 18.8 & 53.4 & 26.7 & 4.06 \\
\hline My curiosity is higher than other people in general. & 0.4 & 1.9 & 21.4 & 49.6 & 26.7 & 4.00 \\
\hline \multicolumn{7}{|l|}{ Challenging: } \\
\hline I love being in new and spectacular situation. & 0 & 7.1 & 26.7 & 45.9 & 20.3 & 3.79 \\
\hline I love trying new recipe. & 0 & 6.0 & 23.3 & 45.1 & 25.6 & 3.90 \\
\hline $\begin{array}{l}\text { I love taking different directions that I have never } \\
\text { traveled. }\end{array}$ & 0.8 & 3.0 & 24.8 & 50.4 & 21.1 & 3.88 \\
\hline I like doing new things differently. & 0.4 & 2.3 & 18.0 & 54.9 & 24.4 & 4.01 \\
\hline $\begin{array}{l}\text { My daily life is filled with new experiences that } \\
\text { make me excited. }\end{array}$ & 0 & 4.5 & 29.3 & 47.4 & 18.8 & 3.80 \\
\hline \multicolumn{7}{|l|}{ Connection } \\
\hline I behave well to friends. & 0.8 & 0.8 & 10.2 & 52.6 & 35.7 & 4.22 \\
\hline My friends have positive impressions on me. & 0.8 & 1.5 & 16.2 & 52.6 & 28.9 & 4.08 \\
\hline I forget others' mistakes quickly & 1.9 & 7.5 & 25.9 & 47.4 & 17.3 & 3.71 \\
\hline
\end{tabular}

$\mathrm{SD}=$ Strongly disagree; $\mathrm{D}=$ Disagree; $\mathrm{N}=$ Neutral; $\mathrm{A}=$ Agree; $\mathrm{SA}=$ Strongly Agree

Table: 5 Employees' engagement profiles

\begin{tabular}{|c|c|c|c|c|c|c|}
\hline \multirow[t]{2}{*}{ Descriptions } & SD & $\mathrm{DA}$ & $\mathrm{N}$ & A & SA & Mean \\
\hline & & & \multicolumn{4}{|l|}{$\%$} \\
\hline \multicolumn{7}{|l|}{ Enthusiasm: } \\
\hline I feel very full of energy at work. & 0.4 & 1.9 & 20.7 & 50.8 & 26.3 & 4.01 \\
\hline I feel strong and excited at work. & 0.8 & 2.3 & 19.5 & 51.9 & 25.6 & \\
\hline \multicolumn{7}{|l|}{ Dedication: } \\
\hline $\begin{array}{l}\text { I am excited to wake up in the morning to start } \\
\text { working. }\end{array}$ & 0.8 & 4.9 & 19.5 & 42.9 & 32.0 & 3.99 \\
\hline I like to work continuously. & 1.9 & 12.0 & 32.7 & 35.7 & 17.7 & 4.00 \\
\hline I am enthusiastic about my work. & 1.1 & 1.9 & 15.8 & 52.6 & 28.6 & \\
\hline \multicolumn{7}{|l|}{ Work appreciation: } \\
\hline I get inspiration from the work I do. & 1.1 & 1.9 & 22.2 & 52.6 & 22.2 & 3.55 \\
\hline I am proud of my job. & 1.1 & 1.5 & 12.8 & 48.5 & 36.1 & 4.06 \\
\hline I love my job. & 1.1 & 1.9 & 13.2 & 50.4 & 33.5 & 3.93 \\
\hline
\end{tabular}

Table:6 Interpretation of mean

\begin{tabular}{lcc}
\hline Interval & \multicolumn{2}{c}{ Interpretation } \\
\cline { 2 - 3 } & Employees' resilience & Employees' work engagement \\
\hline $1.00-1.20$ & The lowest & The lowest \\
$1.21-2.40$ & Low & Low \\
$2.41-3.60$ & Adequate & Adequate \\
$3.61-4.80$ & High & High \\
$4.81-5.00$ & The highest & The highest \\
\hline
\end{tabular}


According to the indicator interpretation of mean, the study found that the respondents state of 'I behave well to friends' (mean 4.22). It means that they think they have high resilience. Next, the respondents state of ' $I$ forget others' mistakes quickly' (mean 3.71). This implies that the respondents easy to forget other persons' mistakes. Those conditions related to the previous study. The previous study found that resilience employees have the capacity to overcome negative emotions, adapt to a changing environment (Hu et al., 2015; Niitsu et al., 2017) and unpleasant experience (Fagan, 2019)

For employees' work engagement the study found that the highest mean is for the statement 'I am proud of my job' (mean 4.01). Based on that mean, it implies the respondents have high pride of their jobs. Unfortunately, the lowest mean (3.55) is for the statement 'I get inspiration from the work I do'. It means that the respondents aren't sure if their job will inspire them. These situation are supported by the previous research that the employees who have excellent work engagement will have positive behavior, totality, focus on work, enthusiasm, dedication and work appreciation (Schaufeli et al., 2014; Rian, 2017). The higher employees work engagement, the higher their innovative behavior (Yho, 2018; Yucheng, 2017). Finally, it will lead to higher work performance (Karatepe, 2014).

\section{Pearson Correlation Test}

Pearson correlation analysis is for determining the strength of the relationship between variables (Santoso, 2014: 315). The range of correlation values is shown in figure 2 .

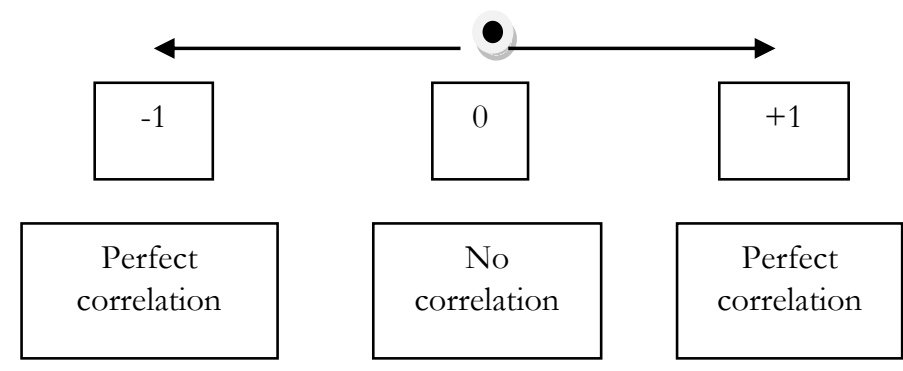

Figure 2: Pearson correlation interpretation (Santoso, 2014:315)

The value of 0.5 indicates a strong enough correlation, while below a weak correlation. The (-) sign in the output indicates the opposite direction of the relationship, while the $(+)$ sign indicates the same direction. 
Table: 7 Correlation test result

\begin{tabular}{llrr}
\hline & & $\begin{array}{r}\text { Employees' } \\
\text { resilience }\end{array}$ & $\begin{array}{r}\text { Employees' work } \\
\text { engagement }\end{array}$ \\
\cline { 3 - 4 } Employees' & Pearson Correlation & 1 & $.782^{* *}$ \\
resilience & Sig. (2-tailed) & & .000 \\
& $\mathrm{~N}$ & 266 & 266 \\
Employees' work & Pearson Correlation & $.782^{* *}$ & 1 \\
engagement & Sig. (2-tailed) & .000 & 266
\end{tabular}

**. Correlation is significant at the 0.01 level (2-tailed).

Pearson correlation analysis results show that the relationship of employees' resilience to employees' and employees work engagement is 0.782 ( $>$ $0.5)$, this means that employees' resilience has a strong relationship to employees' work engagement. The positive value concluded that the higher employees' resilience, there will be the higher employees' work engagement. It's understood because employees' work engagement describes the relationship between employees and their work environment (Schaufeli et al., 2006; Christian et al., 2011; Karatepe, 2014).

\section{Coefficient Determination}

\begin{tabular}{lcrrr}
\multicolumn{4}{c}{ Table 8: Coefficient determination $\left(\mathrm{R}^{2}\right)$} \\
\hline Model & $\mathrm{R}$ & R Square & $\begin{array}{c}\text { Adjusted R } \\
\text { Square }\end{array}$ & $\begin{array}{c}\text { Std. Error of the } \\
\text { Estimate }\end{array}$ \\
\hline 1 &, $782^{\mathrm{a}}$ &, 611 & 610 & 3,377 \\
\hline a. Predictors: (Constant), employees' resilience & & &
\end{tabular}

The analysis shows that $\mathrm{R}$ Square is 61.1 percent, which means that employees' resilience affects their work engagement by 61.1 percent while $39.9 \%$ is influenced by other variables that is not examined in this study. For further study, it is interesting to examine how leadership changes could affect work engagement (Li et al., 2012).

\section{Linear Regression}

Simple linear analysis shows the regression equation as follows: $\mathrm{Y}=\mathrm{a}+$ $\mathrm{bX}$ or $\mathrm{Y}=2.202+574 \mathrm{X}$. This equation implies that if employees do not have resilience (variable $\mathrm{X}=$ zero) then employees' work engagement will 2.202 points. Moreover, if employees' resilience increases 1 point, employees work engagement will increase 0.574 points. Positive regression equation means that the higher employees' resilience, the higher employees' work engagement.

Table 9: Linear regression

\begin{tabular}{|c|c|c|c|c|c|}
\hline \multicolumn{6}{|c|}{ Coefficients $^{a}$} \\
\hline \multirow[t]{2}{*}{ Model } & Unstandardi & d Coefficients & Standardized Coefficients & $\mathrm{t}$ & Sig. \\
\hline & $\mathrm{B}$ & Std. Error & Beta & & \\
\hline 1 (Constant) & 2,202 & 1,470 & & 1,498 & 135 \\
\hline TotalRsc &, 574 & 028 & 782 & 20,373 & ,000 \\
\hline
\end{tabular}




\section{T-test}

Based on the significance value, if Sig. $<0.05$ then there is the effect of employees' resilience on employees' work engagement. Sig.> 0.05 then there is no effect of employees' resilience on employees' work engagement.

The hypothesis in this study:

Ho: There is no positive and significance effect of employees' resilience on their work engagement at hotels in Jakarta

Ha: There is positive and significance effect of employees' resilience on their work engagement at hotels in Jakarta.

The $\mathrm{t}$ test shows the significance value of the variable Sig. 0,000> probability 0.05 then $\mathrm{Ho}$ is rejected and $\mathrm{Ha}$ is accepted or there is positive and significance effect of employees' resilience on their work engagement of hotel employees in Jakarta. It's good result that employees at hotels in Jakarta have resilience. Because employees who has resilience will not easily influenced by negative behavior (Riff and Singer, 1996).

\section{F. Conclusion}

Hotel employees play an important role in providing services to guests. They must be able to serve guests well, without any complaints from them. This is not easy, considering that hotels have heavy operational work. Moreover, up to now the level of welfare of hotel employees have not been sufficiently competitive with other industries. The challenge for Human Resource Manager is how to build high employees resilience, because based on the result of this study indicate that - the higher employees' resilience, the higher their work engagement will be.

\section{G. Acknowledgement}

We would like to thank Trisakti School of Tourism for funding the research of 'Is the higher employees' resilience, the higher their work engagement will be?'

\section{REFERENCES}

Christian,M.S., Garza, A.S., dan Slaughter,J.E. (2011). Work engagement: A quantitative review and test of its relations with task and contextual performance. Personnel Psychology, 64(1), 89-136.

Connor, K.M., dan Davidson, J.R.T. (2003). Development of a new resilience scale: The Connor-Davidson resilience scale (CD-RISC). Depression and Anxiety, 18(2), 76-82. 
Fagan, O.(xxxx). Building resilience: Inspire workplaces wellbeing at work. Retrieved from: https://www.ucd.ie

Fredrickson, B.L., Cohn, M.A., Coffey, K.A., Pek, J., dan Finkel, S.M. (2008). Open hearts build lives: Positive emotions, induced through lovingkindness meditation, build consequential personal resources. Journal of Personality and Social Psychology, 95(5), 1045.

Hu, T., Zhang, D., dan Wang, J. (2015). A meta-analysis of the trait resilience and mental health. Personality and individual differences, 76, 18-27.

Hyo S.J., dan Hye H.Y.(2018).Improving frontline service employees' innovative behavior using conflict management in the hospitality industry: The mediating role of engagement. Tourism Management, vol.69, 504-505.

Karatepe, O.M., dan Shahriari, S. (2014). Job embeddedness as a moderator of the impact of organizational justice on turnover intentions: A study in Iran. International Journal of Tourism Research, 16(1), 22-32.

Karatepe, O.M., Beirami,E., Bouzari,M., dan Safavi, H.P. (2014). Does work engagement mediate the effects of challenge stressors on job outcomes? Evidence from the hotel industry. International Journal of Hospitality Management, 36, 14-22.

Li, X., Sanders, K., dan Frenkel, S. (2012). How leader-member exchange, work engagement and HRM consistency explain Chinese luxury hotel employees' job performance. International Journal of Hospitality Management, 31(4), 10591066.

Masten, A.S. (2001). Ordinary magic: Resilence processes in development. American Psychologist, 56(3), 227-238.

Niitsu,K., Houfek, J.F., Barron, C.R., Stoltenberg, S.F., Kupzyk, K.A., dan Rice, M.J. (2017). A concept analysis of resilience integrating genetics. Issues in Mental Health Nursing, 38(11), 896-906.

Rian, P., dan Zamralita. (2017). Gambaran work engagement pada karyawan di PT, EG (manufacturing industry). Jurnal Muara Ilmu Sosial, Humaniora, dan Seni, 1(2), 295-303.

Ryff, C.D., dan Singer, B. (1996). Psuchological well-being: Meaning, measurement, and implications for psychoterapy research. Psychotherapy and Psychosomatics, 65(1), 14-23.

Soutwick, S.M.; George, A.B.; Ann, S.M.; Chaterine, P.B.; dan Rachel, Y.(2014). Resilience definitions, theory, and challenges: Interdisciplinary perspectives. Article in European of Psychotraumatology,

Schaufeli, W.B., dan Bakker, A.B. (2014). Defining and measuring work engagement: Bringing clarity to the concept.Retrieved from: https://www.researchgate.net/

Schaufeli,W.B., Bakker, A.B., dan Salanova, M. (2006). The measurement of work engagement with a short questionnaire: A cross-national study. Educational and Psychological Measurement, 66(4), 701-716. 
Yucheng Z., Yongxing G., dan Alexander N. (2017). Identity judgements, work engagement and organizational citizenship behavior: The meadiating effects based on group engagement model. Tourism Management, vol.61, 190197.

Santoso, Singgih, 2014. Panduan Lengkap SPSS Versi 20, edisi Revisi. Kompas Gramedia, 315. 